\title{
Article
}

\section{The impact of maturing food safety culture and a pathway to economic gain}

Jespersen, Lone, Butts, John, Holler, Greg, Taylor, Jeff, Harlan, Dave, Griffiths, Mansel and Wallace, Carol Anne

Available at http://clok.uclan.ac.uk/25353/

Jespersen, Lone, Butts, John, Holler, Greg, Taylor, Jeff, Harlan, Dave, Griffiths, Mansel and Wallace, Carol Anne ORCID: 0000-0002-1402-2134 (2019) The impact of maturing food safety culture and a pathway to economic gain. Food Control, 98 . pp. 367-379. ISSN 0956-7135

It is advisable to refer to the publisher's version if you intend to cite from the work. http://dx.doi.org/10.1016/j.foodcont.2018.11.041

For more information about UCLan's research in this area go to http://www.uclan.ac.uk/researchgroups/ and search for <name of research Group>.

For information about Research generally at UCLan please go to http://www.uclan.ac.uk/research/

All outputs in CLoK are protected by Intellectual Property Rights law, including Copyright law. Copyright, IPR and Moral Rights for the works on this site are retained by the individual authors and/or other copyright owners. Terms and conditions for use of this material are defined in the policies page.

\section{CLoK}

Central Lancashire online Knowledge www.clok.uclan.ac.uk

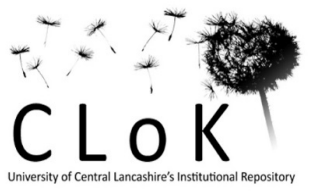



Authors

3 Lone Jespersen ${ }^{1}$, John Butts ${ }^{2}$, Greg Holler ${ }^{3}$, Jeff Taylor ${ }^{4}$, Dave Harlan ${ }^{3}$, Mansel Griffiths ${ }^{1}$, and 4 Carol Wallace 5

5 (1) Department of Food Science, University of Guelph, 50 Stone Road East, Guelph, ON N1G $6 \quad 2 M 7$, Canada

7 (2) Land O'Frost, 911 Hastings Ave, Searcy, AR, USA

8 (3) Cargill Incorporated, PO Box 9400, Minneapolis. MN 55440, USA

9 (4) Bush Brothers, 122 Perimeter Park Rd., Knoxville, TN 37922, USA

10 (5) University of Central Lancashire, International Institute of Nutritional Sciences and Applied 11 Food Safety Studies, Preston, Lancashire PR1 2HE, United Kingdom.

Abstract Research into the connection between organizational effectiveness and culture has been

15 documented since the early nineteen nineties. A connection between economic performance and 16 organizational culture has been established directly linking strong cultural drivers to economic 17 performance in both the finance and retail sectors. This research proposes a similar association 
18 between food safety culture, the measures of maturity and cost of poor quality. Through data

19 collected at five multi-national food companies, this association is explored, and an improved

20 food safety maturity model suggested. The authors also propose a dynamic model of food safety

21 culture, segmenting it into 4 building blocks: I. Organizational effectiveness, II. Organizational

22 culture norms, III. Working group learned and shared assumptions, and behaviours, and IV.

23 Individual intent and behaviours; and discuss the crucial role of actions between building blocks

24 as part of the pathway to realizing economic gain.

$25 \quad$ Highlights

26 1. Explores organizational culture, effectiveness, and performance in the food industry

27 2. Demonstrates theoretical economic gain from building food safety culture maturity

28 3. Refines and strengthens a food safety culture maturity model for practical application

29 4. Proposes a dynamic model of food safety culture building block and interactions

30 5. Empirical study of culture performance within five global food manufacturing companies

$31 \quad$ Keywords

32 Food safety culture, economic impact, food safety maturity model, cost of poor quality,

33 food safety culture dynamic model. 


\section{Introduction}

To solve the specific challenges related to food safety performance, e.g., consumer death,

38 illness and injury (Maberry, 2016; World-Health-Organization, 2015), and impact on brand and

39 economics (Hussain \& Dawson, 2013; Ribera et al., 2012) throughout the food supply chain it is

40 now widely recognized that food safety culture plays an integral role (Ball, Wilcock, \& Aung,

41 2009; Griffith, 2010; Griffith \& Jackson, 2017; Nayak \& Waterson, 2017; Powell, Jacob, \&

42 Chapman, 2011; Taylor, 2011). It is also understood that to get to a stronger sub-culture (e.g.,

43 safety culture, food safety culture, innovation culture) one must consider the broader

44 organizational culture and its effectiveness (Denison, Hooijberg, Lane, \& Lief, 2012; Denison \&

45 Mishra, 1995; Schein \& Schein, 2017). Quoting Harvard Professor Emeritus James L. Heskett,

46 "Organization culture is not a soft concept, its impact on profit can be measured and quantified.

47 And in organizations with large numbers of customer-facing employees, the sum of the effects of

48 employee turnover, referrals of potential employees by existing ones, productivity, customer

49 loyalty, and referrals of new customers attributable to culture can add up to half of the difference

50 in operating income between organizations in the same business" (Kotter \& Heskett, 1992). It is

51 this contrast between perceived soft (e.g., principles of organizational and behavioural sciences)

52 and hard (e.g., financial performance) concepts that makes organizational cultures and sub-

53 cultures both intriguing and challenging for practitioners and scientists to understand and makes

54 it important to conduct further work to elucidate how these concepts apply in different settings,

55 e.g., food manufacturing, thus addressing the research gaps in these areas. 
Crosby (1972) defines quality as 'conformance to requirements' and makes the claim that

57 "management unintentionally cause an increased cost of quality for the organization by not

58 understanding this simple definition." Crosby also suggests, like Kotter and Heskett (1992), that

59 a culture revolution through a planned strategy is the key to reducing cost of quality in any

60 organization. Through the 'Quality Management Maturity Grid', Crosby defines six

61 measurement categories by which an organization can evaluate its current stage of quality

62 maturity. Using the grid, he demonstrates the connection between decreasing cost of quality and

63 increasing quality culture maturity; thereby directly linking the culture of an organization to

64 organizational financial performance. Crosby shows how as much as $20 \%$ of sales can be lost as

65 cost of poor quality (COPQ) in contrast to losses in a high-level maturity culture of $2.5 \%$. The

66 American Society of Quality (ASQ) builds on the work by Crosby and divides COPQ into four

67 activities: prevention costs, appraisal costs, and internal and external failure costs (Duffy, 2017).

68 Through these activities, costs related to e.g., systems maintenance and training, conformance to

69 specification, verification activities, waste and scrap, and complaints, are tracked to quantify the

70 percentage of sales due to poor quality. Schiffauerova and Thomson, (2006) report that each

71 industrial sector has unique quality cost elements but that there is no set structure or accounting

72 standard for quality costing (Schiffauerova \& Thomson, 2006). Thus, the decision on the cost

73 structure of the COPQ model is generally left to the judgment of quality managers and may

74 differ considerably between companies. Nevertheless, since prevention, appraisal, and review of

75 internal and external failures have been related to food safety management effectiveness in food

76 manufacturing companies (Hutton, 2001; Surak \& Wilson, 2007; Wallace, Sperber, \&

Page 4 of 45 
77 Mortimore, 2010), it is logical to surmise that costs of these activities will form quality cost

78 elements for calculating COPQ in food manufacturing. Thus, the authors of this research suggest

79 that COPQ, as defined by Crosby and ASQ and applied to food companies, includes specific

80 food safety metrics (Table 1) and is therefore a relevant measure for estimation of economic

81 impact of a company's food safety culture maturity, although this has not yet been tested by

82 empirical research.

(Table 1)

$84 \quad$ In order to further explore the potential impact of food safety culture maturity on

85 economic indicators such as COPQ, it is necessary to establish the relevant theoretical

86 background in organisational and food safety culture. This now follows along with a delineation

87 of the aims of this research.

\section{Theoretical background and research aims}

Principles from organizational culture have been incorporated into research on food

91 safety culture by most of the researchers in the field. As such, the authors seek to provide a

92 review of research that specifically focused on showing the connection between organizational

93 culture, organizational effectiveness and the impact of both on economic performance.

94 Kotter and Heskett (1992) studied culture in 207 U.S. firms through surveys and detailed

95 interviews and found a direct connection between organizational culture and financial 
96 performance. While the authors clearly stated that many confounding variables impact an

97 organization's financial performance, they also discovered a substantial difference in financial

98 performance between performance-enhancing cultures and non-performance enhancing cultures

99 within two groups of 12 companies (Table 2). In the group that invested in a performance-

100 enhancing culture, the increase across the financial indicators ranged from more than $200 \%$ to

101 more than 900\% for specific indicators. Kotter and Heskett (1992) described 'performance-

102 enhancing cultures' as those which have organizational values that include managers deeply

103 caring about customers, and strongly value people and processes that create useful change.

104 Conversely values in non-performance enhancing cultures are described as managers mostly

105 caring about themselves and their immediate work group and emphasising consistent

106 management processes that reduce risks within their immediate area of responsibility.

107 (Table 2)

108 Similar to Kotter and Heskett (1992) Denison (1997) explored the connection between

109 organizational culture and effectiveness. Denison's research sought to answer the question "what

110 can the cultural characteristics of an organization tell us about effectiveness?" and demonstrates

111 the connection between four organizational traits: Involvement, Consistency, Adaptability, and

112 Mission and organizational effectiveness. Denison measured organizational effectiveness

113 through behavioural performance using the established scale 'Survey of Organizations (SOO)'

114 and financial performance through income/sales ratio and income/investment ratio. Denison

115 found a valid connection between these cultural traits to both behavioural performance and 
116 financial effectiveness (Denison, 1997; Denison \& Mishra, 1995). Graham et al. (2017) defined

117 an effective culture as "one that promotes the behaviours needed to successfully execute the

118 firm's strategies and achieve its goals". Data were gathered from 1,348 North American firms

119 through surveys and interviews with senior executives. The authors found that organizational

120 effectiveness is the result of interaction between an organizations values, norms, and formal

121 systems (Graham et al. (2017). In this context, values are defined as the aspirations of the

122 organization, norms as the day-to-day practices that live out the values, and formal systems as

123 their written policies and procedures. Human behaviours are conditioned through the integration

124 and adaptation of organizational norms, and norms are, in turn, an interpretation and adaptation

125 to the organization's values and formal systems. Graham et al. (2017) demonstrates that norms

126 enhance business outcomes, but values do not. Their research also suggests that the marketplace

127 influences executives' investment in culture as well as the organizational values they promote

128 (Graham et al. 2017). This external adaption is also captured in Schein's updated (2017)

129 definition of organizational culture as “... the accumulated shared learning of the group as it

130 solves its problems of external adaptation and internal integration..." (Schein \& Schein, 2017).

131 Schein thereby integrates external and internal triggers of change as confirmed by the findings of

132 Graham et al. (2017).

133 The 'Great Place to Work ${ }^{\circledR}$ Institute' is a global organization dedicated to providing

134 knowledge on how to build and sustain high performing work place culture. Its database contains

135 data from more than 5,500 companies operating in 45 countries collected through annual 
136 assessment surveys and is used for the 'Great Place to Work ${ }^{\circledR}$ Institute' own publications on

137 workplace culture as well as being made available for academic study (Great-Place-to-Work,

138 2017). Through analysis of the survey data, researchers found that proclaimed values appeared

139 irrelevant to an organization's effectiveness (Guiso, Sapienza, \& Zingales, 2014). This supports

140 the findings of Graham et al. (2017) that values alone do not drive business outcomes, but norms

141 do. The research also shows that if executives are perceived as trustworthy and ethical the

142 company's performance will be stronger. In analysing S\&P 500 companies the researchers found

143 that $80 \%$ of the companies mention 'innovation' followed by 'integrity and respect' in their

144 corporate values. A culture of integrity was found to add value and positively correlated with

145 financial performance and attractiveness of job offerings and negatively correlated with the

146 degree to which the company's workforce was unionized or not (Guiso et al. 2014).

147 Causality between culture and organizational effectiveness measured through

148 performance, was proven in a six-year longitudinal study with car dealers. The study proved that

149 'culture does come first' and performance will follow. Further, the positive effect of culture on

150 vehicle sales was fully mediated by customer satisfaction ratings (Boyce, Nieminen, Gillespie,

151 Ryan, \& Denison, 2015).

152 2.2 Measuring food safety culture maturity

153 An extensive list of researchers (Ball et al., 2009; Boeck, Jacxsens, Bollaerts, \& Vlerick, 154 2015; Griffith, 2014; Hinsz \& Nickell, 2015; Jespersen, Griffiths, \& Wallace, 2017; Nayak \& 155 Waterson, 2017; Nickell \& Hinsz, 2011; Nyarugwe, Linnemann, Hofstede, Fogliano, \& Luning, 
156 2016; Powell et al., 2011; Taylor, Garat, Simreen, \& Sarieddine, 2015; Yiannas, 2009) have built

157 the current knowledge base of food safety culture and its assessment and improvement, which

158 the authors seek to further through this research.

159 Focussing on food safety culture maturity, Jespersen et al completed five studies aimed at

160 measuring this construct (Jespersen \& Edwards, Submitted; Jespersen, Griffiths, Maclaurin,

161 Chapman, \& Wallace, 2016; Jespersen, Griffiths, et al., 2017; Jespersen, MacLaurin, \& Vlerick,

162 2017; Jespersen \& Wallace, 2017). The initial study (Jespersen et al., 2016) suggested that by

163 applying a mixed method approach using quantitative (questionnaire) and qualitative (interviews

164 and document coding) elements, a comprehensive insight could be gained through profiling

165 using a maturity model. The initial model was built on principles from organizational culture,

166 specifically Schein's five dimensions (Schein, 2004) as well as learnings from maturity models

167 in other domains: quality management (Crosby, 1972), health care (Goonan, Muzikowski, \&

168 Stoltz, 2009), and information technology (Ali, 2014). The progressive five stage food safety

169 model breaks down food safety culture into five capability areas. To ensure content validity of

170 the model a Delphi method was applied with three rounds of review and revision with a seven-

171 member panel. Following finalization of the model this was applied to the measurement of food

172 safety culture at one Canadian protein company (Jespersen et al., 2016). To validate the model

173 and mixed method a comparative study of eight existing evaluation systems was conducted

174 (Denzin, 2012; Jespersen, Griffiths, et al., 2017). One of the key findings in the comparative

175 study was general weakness in how the evaluation systems were validated. None of the 
176 evaluation systems had applied and published a structured triangulation as a commonly applied

177 method for validating social science scales (Denzin, 2012; Jespersen, Griffiths, et al., 2017). A

178 content analysis method was proposed to accurately reflect an organization's food safety culture

179 (Jespersen, 2017; Jespersen \& Edwards, Submitted; Jespersen \& Wallace, 2017) as well as a

180 method to assess response bias in the form of social desirability (Jespersen, MacLaurin, et al.,

181 2017). Five dimensions of food safety culture ( Values and Mission, People Systems,

182 Adaptability, Consistency, and Risk Awareness) were proposed based on the results from the

183 comparative study (Denzin, 2012; Jespersen, Griffiths, et al., 2017). These dimensions have been

184 adopted by the Global Food Safety Initiative (GFSI) in the GFSI position paper on a culture of

185 food safety (Quentin \& Jespersen, 2018).

\subsubsection{Development of a self-assessment scale}

The scale was developed by Jespersen et al. (2016) and includes question statements

188 pertaining to four areas (Table 3) to measure food safety culture maturity; social norms,

189 behavioural intent, motivation, and social desirability. Social norms are measures that relate to a

190 person's perception of what other people would approve of regarding given behaviours. The

191 individual participants were asked a series of statements 'Most people whose opinion I value

192 would approve of...'. Behavioural intent is measured through statements designed to gauge a

193 participant's intent to carry out a specific food safety behaviour consistently. Motivation in a

194 cultural context is measured by asking the respondent to prioritize who in their social network

195 they are motivated by to carry out food safety behaviours; manager, peers, family/friend, or self. 
196 Social desirability is a social science research measure that quantifies the tendency of study

197 participants to answer questions in a way to be viewed favourably by others. It can take the form

198 of over-reporting 'good behaviour' or under-reporting 'undesirable behaviour' and rated on a

199 scale from zero to 18 . The objective is to get a score of zero where study participants answer

200 truthfully independent of other's views of them. Research can be advanced by considering social

201 desirability, statistically speaking, as a control variable. By measuring humans' tendency to

202 answer food safety related questions in manner that will be viewed favourably by others, the

203 food industry can get a more authentic and valid assessment of food safety culture (Jespersen,

204 MacLaurin, et al., 2017).

205 (Table 3)

\section{$206 \quad$ 2.2.2 Developing a textual coding framework}

207 Textual data, including documents and, following transcription, semi-structured interview

208 data involve large amounts of text that is commonly subjected to content analysis to determine

209 patterns, trends and relationships as well as frequencies of words used in a document or by an

210 interview subject (Vaismoradi et al, 2013). A deductive content analysis approach was chosen in

211 order to apply method triangulation to increase validity of food safety culture evaluation results.

212 This used a coding framework based on the dimensions of food safety culture identified by

213 Jespersen, Griffiths and Wallace (2017) from a study of eight culture or food safety culture

214 evaluation systems. The content analysis of food safety performance documents provided an

215 insight into the documented food safety culture e.g., level of consistency, adaptability, and 
216 perceived value of food safety, whilst the analysis of interview data explored the lived food

217 safety culture as vocalized by the interview subjects.

218 The process for developing the coding framework and coding content was reported by

219 Jespersen and Wallace (2017) and is shown in annex 1. Detailed research questions were

220 defined (step 1) and the theoretical framework of five dimensions of food safety culture

221 (Jespersen, Griffiths and Wallace (2016)) was used as a starting point for determination of

222 coding nodes. Two independent coders first read and re-read the data to gain an immersive

223 sense of the whole before deducing appropriate sub-nodes and establishing the coding

224 framework (step 2). The framework (annex 2) was an important component as it connects the

225 coded data to the theoretical framework and the research domain. The nodes and sub-notes were

226 input into NVivo (step 3) and, following this, coders were trained (step 4) and two documents

227 coded by same coders (step 5). The results were analyzed by detailed review of verbatim data to

228 look for similarities and differences between coders. A decision was made to go back to the

229 coding framework and update with addition of sub-nodes and to go back to the test documents

230 for recoding (step 6). Following this loop, the decision was made to carry on with the full

231 document coding as coders were considered "consistent" based on another detailed verbatim

232 review (step 7). Midway discussions between coders allowed comparison of experience, and

233 discussion of coding difficulties and issues. These results led to another rework of the two

234 selected documents and finalization of the 30 documents (step 8). Finally, the data was analyzed

235 to derive information to answer the research questions (step 9). 
The process included two checks for consistency evaluated through calculation of

237 percentage pairwise agreement. (Neuendorf, 2002) argues that the goal for pairwise agreement in

238 social sciences often are .8 but that .9 levels are most appropriate. This higher threshold level has

239 also been suggested to account for some weaknesses in this method (Lombard, Snyder-Duch, \&

240 Bracken, 2002). Based on these references the standard for this research for pairwise agreement

241 level was set to .9 (90\% agreement).

\section{$242 \quad$ 2.2.3 Constructing the food safety maturity model}

243 The maturity model was designed to assesses food safety culture on a scale from zero to

244 five. The model and scale are sub-divided into five stages each with a description of a capability

245 area e.g., people systems at a given maturity score e.g., three. The descriptor for a company’s

246 people system in a maturity stage three is 'deep understanding for the importance of food safety

247 systems with clearly defined and communicated responsibilities.'

248 Each stage on the maturity scale has two identifiers a numerical and textual i.e., stage

249 1/doubt, stage 2/react to, stage 3/know of, stage 4/predict, and stage 5/internalize. The numerical

250 identifiers are aligned with the scale used in the online self-assessment. For example, a self-

251 assessment of two in the self-assessment equals a 'disagree' on the Likert scale of 'strongly

252 disagree to strongly agree 'and a stage $2 /$ react on the maturity scale. In addition, the maturity

253 scale was aligned to the levels of Crosby’s Quality Management Maturity Grid (Crosby, 1972).

254 To apply the maturity scale, all responses from each of the participants in the self-

255 assessment were added and a mean maturity rating for each capability area and aggregated mean 
256 for all capability areas calculated. Depending on the mean ratings a maturity score for the

257 capability areas, the plant over all, or the company over all could be estimated. As such, maturity

258 ratings could fall into any of the five stages on the maturity scale and model, and an

259 interpretation of stages could be provided based on the descriptors of the stages and the detailed

260 content of the capability areas in the maturity model as shown in the maturity model construct

261 (Table 4).

$262 \quad 2.3$ Research aims

263 As previously stated, gaps were identified relating to the validation of assessment methods

264 (Jespersen, Griffiths and Wallace, 2017) and how food safety culture research has not yet

265 progressed to include an evaluation of organizational performance and effectiveness. Thus, it is

266 not currently possible to determine the impact of food safety culture on the economic

267 performance of a business. Therefore, it is important to understand how validated assessment

268 measures of food safety culture maturity can be combined with economic performance measures

269 such as COPQ to understand how improvement of food safety culture can support business

270 effectiveness. In order to move forward the debate in this area, this research aims to, 1) validate

271 or revise the initial food safety maturity model based on new learnings, 2) apply the principles of

272 cost of poor quality to assess economic value of maturing food safety culture, and 3) suggest a

273 dynamic model that captures the constant interactions that cause sub-cultures to adapt to and

274 integrate change in a food manufacturing setting. 


\section{3. Materials and methods}

276 This research was part of a large study of food safety culture performance conducted in

277 collaboration with five multi-national North American-based food manufacturing companies

278 from October 2015 to March 2016.

279 3.1 Data collection at five global food manufacturing companies

280 Five companies were approached to participate in the study based on their previous

281 interests in the subject and willingness to have the researcher collect data virtually and on-site in

282 all their manufacturing plants. Study data collection methods included an online survey,

283 interviews and review of performance documents. Data were collected from 21 food

284 manufacturing plants and 1,273 leaders in executive, management, and supervisory roles from all

285 functional areas were asked to participate in the online survey, 379 documents were collected

286 and coded, and 42 on-site interviews were conducted and coded (Table 5).

287 (Table 5)

288 3.2 Maturity calculation using method triangulation

289 Three methods were applied in the study of triangulation (Jespersen and Wallace, 2017)

290 with the aim of collectively minimizing the method weaknesses of the individual methods and

291 providing complementary data from the plants under investigation based on the strengths and

292 practicalities of each: Method 1- Self-assessment scale, analyzed quantitatively using SPSS;

293 Method 2 - Performance document content analysis, qualitative analysis using NVivo; : Method 
2943 -Semi-structured interviews, qualitative analysis using NVivo. Strengths and weaknesses of 295 each method were explored and are reported elsewhere (Jespersen and Wallace, 2017). For 296 example, survey and interviews can help assign causation, survey can help mitigate impact of

297 interviewer skill and experience, content can help penetrate the group language and symbol 298 mechanisms, content and survey can get data to close the attitude to behaviour gap, survey social 299 desirability and interviews can help identify insincere respondents. Application of the methods 300 was as follows: Method 1: Self-assessment scale. All salaried staff in each manufacturing plant were 302 invited to participate in an online survey between November 2015 and March 2016. The scale 303 was developed by (Jespersen et al., 2016) and included questions pertaining to four areas to 304 measure food safety culture maturity; social norms, behavioral intent, motivation, and social 305 desirability. Response data were imported into SPSS [Computer Software] IBM Corporation, 306 New York, U.S.A. from Qualtrics [Computer Software] Qualtrics, Provo, Utah, USA and readied 307 (e.g., removal of incomplete data sets, reversal of negative scales) for analysis. An aggregated 308 maturity score (mean and standard deviation) as well as maturity level by dimension (mean and 309 standard deviation) were calculated for each plant with control for social desirability score 310 (Jespersen, MacLaurin, et al., 2017). Method 2: Content analysis of performance documents. Each of the manufacturing plants 312 were asked to share food safety documents (e.g., food safety audit reports, food safety meeting 313 minutes, inspection reports, and Good Manufacturing Practice (GMP) records) dating back 12- 
314 months from November 2015. Content analysis was applied to these documents using the

315 predefined coding framework of Jespersen and Wallace (2017) (See 2.4 and Annexes 1 and 2)

316 which was translated into nodes in NVivo [Computer Software] QSR International, Doncaster,

317 Australia. Each document was imported into NVivo and all documents were coded by two

318 researchers.

Method 3: Content analysis of semi-structured interviews. Semi-structured interviews

320 with senior plant leader and senior food safety leader were arranged through the participating

321 company sponsors. Senior leaders at a plant were all invited to participate and the focus on

322 senior leaders was chosen as direction for an organizations culture is generally set at a senior

323 level (Denison et al., 2012; Graham, Harvey, Popadak, \& Rajgopal, 2017). Interview questions

324 were shared in advance with the interviewees and informed consent obtained for each interview.

325 All interviews were recorded and each audio file transcribed and codified to ensure anonymity of

326 the interview and uploaded to NVivo for content analysis. The same coding framework was used

327 for the interview files as the food safety documents (Jespersen and Wallace, 2017) (See 2.4 and

328 Annexes 1 and 2).

329 3.3 Further development of the food safety maturity model

330 Based on the findings in this research the model was revised to incorporate learnings

331 from the five companies and increase its applicability. As such, the capability areas were

332 evaluated against the dimensions found in the comparative analysis (Jespersen, Griffiths, et al.,

333 2017) and amended to better integrate learnings from organizational culture e.g., the first model

Page 17 of 45 
334 was found to have an overemphasis on the dimension 'consistency' through the capability areas

335 process thinking, technology enabler, and tools/infrastructure but an under representation of the

336 dimension 'adaptability' which was found to assess how an organization's culture prepares,

337 accepts, and sustains changes. The capability characteristics were also reviewed to better

338 understand if these were described as organizational norms e.g., 'people system' in stage react

339 'Individuals are recognized sporadically after having solved a food safety problem' was not

340 changed as this was already defined as an organizational norm whereas the capability area

341 'perceived value' in stage internalized 'ongoing business improvement and growth enabled by

342 food safety' was found not defined as an organizational norm and redefined to 'Frontline

343 employees are trusted to act correct and celebrate food safety performance on their line/in their

344 area.' The content for each value and stage intersect was redefined as norms by finishing the

345 sentence 'Food safety $<$ VALUE $>$ at company $x$ can be described as $<$ STAGE $>$ through ...' This

346 was different from the content of the original model (Jespersen et al. 2016) where content was

347 derived by summarizing the behaviours behind each capability area and stage. This method ties

348 dimensions, values, and norms to food safety culture through each stage of maturity, resulting in

349 a model that is simpler for organizations to apply in the context of their own organizational

350 values and norms. This also provides a path to improve food safety culture directly tied to stated

351 value, norms, and organizational effectiveness as demonstrated by other studies (Denison et al.,

352 2012; Graham et al., 2017; Kotter \& Heskett, 1992). A fifth dimension specific to 'Hazards and

353 Risks' was added as this was a significant topic during the interviews and was included to reflect

354 the importance of organizational awareness specific to a company's products and processes. 
355 This dimension was also found to be included in other food safety culture assessment systems

356 (De Boeck, Mortier, Jacxsens, Dequidt, \& Vlerick, 2017) through the comparative analysis of

357 Jespersen, Griffiths and Wallace (2017).

$358 \quad 3.4$ Estimation of cost of poor quality

359 The cost of poor quality (COPQ) was calculated using the proposed percentage of sales

360 per maturity stage (Table 6) (Crosby, 1972).

To enable this calculation, the stage descriptors in the food safety maturity model were

363 aligned to the stages of the Crosby model. For example, Crosby's stage 1 describes a stage of

364 'reacting' 'blaming' hiding', and 'firefighting' similar behaviours are included in the stage 1 of

365 the food safety maturity model. The Crosby model also describes a progressive maturation from

366 reacting to understanding to integration of quality. The food safety model applies a similar

367 progressive maturation specific to food safety.

368 The COPQ results were estimated by applying the percentages in table 6 to each of the

369 company's annualized sales in U.S. dollars and the mean maturity that had been calculated using

370 the triangulation method. A mean COPQ (based on actual maturity assessment) and estimates for

371 moving one stage up and one stage down on the maturity model were estimated to illustrate the

372 cost of a deteriorating food safety culture compared to an improved food safety culture. 
373 These estimates are indented to illustrate the potential economic impact of food safety maturity

374 and to call upon further empirical research to validate the food safety components of each of the 375 four components of COPQ (table 1).

3763.5 Development of dynamic model for food safety culture

377 Through the study of existing research of organizational culture, organizational

378 effectiveness, and economic impact (Denison, 1997; Graham et al., 2017; Kotter \& Heskett,

379 1992) a summary of key learnings was developed and this information was used to identify

380 potential building blocks of a dynamic model for food safety culture. The findings from this

381 existing research in organizational culture were augmented with the findings from research of

382 food safety culture where predictive validity had been proven by Ball (Ball et al., 2009), De

383 Boeck (De Boeck et al., 2017), Hinsz (Hinsz \& Nickell, 2015), Jespersen and Edwards

384 (Jespersen \& Edwards, Submitted), and the results of this study. Synthesising the information

385 from these sources and discussion and integration within this academic and industry-based

386 research team allowed the establishment of likely building blocks and design of the suggested

387 model of dynamic interactions between building blocks. 
4.1 Organizational characteristics

Organizational characteristics were calculated based on demographic data collected in

392 the survey (Table 7).

Mean age of respondents ( $n=816)$ was $34-44$ years, with $10-14$ years of experience in the

395 food industry and current company, and 5-9 years in current role. Comparing the individual company mean to this baseline group mean, respondents in company A were older - 45-54 years.

397 Respondents in company B had less experience in both current company and role - 5-9 years.

398 Respondents in company C also had less experience - 5-9 years in current company but 2-4

399 years in role and thereby the least experience in the study. Respondents in company D were older

400 than the mean baseline - 45-54 years and had the longest tenure in the industry - 15-19 years and

401 the company and role - 10-14 years. Respondents in company E also had shorter tenure in their

402 current role - 2-4 years, but unlike company $\mathrm{C}$, were at baseline for experience in both industry

403 and company - 10-14 years. Mean industry tenure $(F(3,925)=6.88, p<.001)$, company

404 tenure $(F(3,925)=5.74, p<.001)$, tenure in current role $(F(3,925)=5.89, p<.001)$ and age $405(F(4,925)=7.65, p<.001)$ were all found to be significantly different between the companies.

406 Functional ratios (\%MFG/\%FSQ) for companies A, B, and D were similar - 86/13, $40782 / 18$, and 85/12. Respondents from company C were mostly involved in manufacturing - 92/8; 
408 while company E had the lowest participation from manufacturing - 78/22. Despite these

409 differences, many respondents in all companies were, not surprisingly, from manufacturing. It

410 should be noted that manufacturing in this context includes all functions except food safety and

411 quality with a direct reporting relationship to a senior manufacturing leader e.g., S. VP

412 Manufacturing or plant manager (e.g., sanitation, maintenance, and finance).

413 The span of control ratios (\%Leader/\%Supervisor) for companies A and E were similar -

$414 \quad 37 / 63$ and 35/65 - with these companies providing most supervisors in the study. Respondents

415 for company B had slightly more supervisors responding at 46/54 and company’s C and D had

416 the most leaders of the five companies responding - 58/42 and 55/45.

$417 \quad 4.2$ Food safety maturity

418 Based on the self-assessment scale, aggregated maturity for companies A, B, and D were 419 in the 'Know' stage at 3.36, 3.31, and 3.05. Company $\mathrm{C}$ had the lowest maturity of 2.80 and in 420 the 'React' stage. Finally, company E had the highest maturity of 4.01 and in the 'Predict' stage 421 (Table 8).

422 Maturity was found to be significantly different $(F(4,785)=5.727, p<.001)$ across the 423 five companies. In analysing social desirability, the companies were also found to be 424 significantly different, $(F(4,460)=10.079, p<.001)$. Companies A and E scored the lowest at 425 mean 4.10 and 4.98 out of a total possible score of 18 . Company $\mathrm{C}$ had the highest score of all at 4267.56 with companies B and D lower at 7.16 and 6.67 respectively. Maturity was also found to be 
427 significantly different between functions $(F(4,460)=10.079, p<.001)$. FSQ rated on average

428 maturity $16 \%$ higher than manufacturing and other functions. Span of control also influenced

429 maturity ratings and were significantly different $(F(4,460)=10.079, p<.001)$. As such,

430 average maturity rating of supervisors was $28 \%$ lower than that of leaders. This supports the

431 findings by Manning (2017) who investigated the impact of subcultures on food safety

432 management and the stratification that naturally occurred due to these sub-cultures (Manning,

433 2017).

434 The individual triangulation scores (Figure 1) shows how the assessment results vary by method

435 with the self-assessment scores (black circle) tends to show a higher maturity score then those of

436 the interviews and performance document reviews.

437 (Figure 1)

$438 \quad 4.3$ Revised food safety maturity model

439 Based on the method described in section 3.3. food safety maturity model 1.0 (Jespersen

440 et al., 2016) was updated to version 2.0 (Table 9). Dimensions and values that were updated are

441 highlighted in table 9.

Page 23 of 45 
442 Table 1: Food safety culture - maturity model version 2.0

443

444 (Table 9) 
447 followed by company $\mathrm{C}$ with the second highest COPQ due to its low maturity rating.

448 Collectively it is estimated that the companies spent \$1.14 billion in sales on COPQ annually in

449 their current stages of maturity. If they all slide down one maturity stage they would spend an

450 additional $\$ 0.38$ billions of sales and if they all move up one stage they save an additional $\$ 0.43$

451 billions of sales (Figure 2).

452 (Figure 2)

$454 \quad 4.5$ Suggested model of dynamic interactions in food safety culture

455 The suggested model of dynamic interactions developed through this research is portrayed in

456 Figure 3. This is presented as a model for further testing and examples are given to illustrate the

457 dynamic nature of the model and the connectivity between the building blocks and interactions in 458 response to a food safety marketplace trigger.

The structure consists of cultural building blocks and dynamic interactions. Each building

460 block is connected to others through the interactions. There are four main building blocks; I.

461 Organizational effectiveness, II. Organizational culture norms, III. Working group learned and

462 shared assumptions, and behaviours, and IV. Individual intent and behaviours. There are seven

463 interactions between the building blocks that indicate how each building block is either 
464 influenced or is influencing. For example, the external environment influences an organizations

465 culture and norms e.g., recall of products from a competitor, a shortage of qualified employees

466 (arrow \#1). Such interactions can cause a review of formal systems arrow e.g., are policies and

467 procedures actually guiding behaviours and actions everyday? (arrow \#2) and the organizations

468 values e.g., is a value of 'integrity' translated in to behaviours of 'see something - say

469 something' everyday? (arrow \#3) which in turn triggers an alignment of values to the formal

470 systems e.g., is a value of 'integrity' translated into the formal system for performance

471 evaluation? The organizations norms influence how working groups take decisions everyday

472 e.g., recognizing those that consistently bring forward issues to solve (arrow \#5) and the

473 individual's intent to behave (arrow \#6 and \#7) e.g., 'I see others get recognized by our manager

474 when speaking up, I better do so as well if something needs correction.

$475 \quad$ (Figure 3)

\section{5. Discussion}

This research sought to address three areas to further the scientific knowledge base for

478 food safety culture, 1) validating or revising the initial food safety maturity model based on new

479 learnings, 2) applying the principles of cost of poor quality to assessing economic value of

480 maturing food safety culture, and 3) suggesting a dynamic model that captures the constant

481 interactions that cause cultures to adapt to and integrate change. 
By applying three data collection methods (Jespersen \& Wallace, 2017) the research was

483 able to calculate a food safety maturity score for five global companies and 21 of their

484 manufacturing plants. The companies aggregated maturity scores were found to be significantly

485 different and ranging from stage 2 - Doubt - to stage 4 - Predict of the food safety maturity

486 model. The qualitative data gathered through the coding of 379 performance documents and 42

487 interviews with plant leaders and food safety managers were applied to further develop the

488 existing food safety maturity model (Jespersen et al 2016). The maturity model was redefined to

489 provide a path for food manufacturers seeking to improve their food safety culture and to provide

490 a link to existing literature on cost of poor quality as a function of organizational maturity

491 (Crosby, 1972; Duffy, 2017; Schiffauerova \& Thomson, 2006). It was found that dimensions of

492 food safety culture could be described across the maturity model stages in forms of norms, e.g.,

493 'Frontline teams and supervisors make use of leading indicators to improve food safety systems'

494 (dimension $=$ consistency), to better integrate food safety into a food company's existing values.

495 A fifth dimension was added 'Risks and Hazards' to better link the importance of hazard

496 awareness and learnings from HACCP deployment (Wallace, 2009; Wallace, Holyoak, Powell,

497 \& Dykes, 2012). This Risks and Hazards dimension was identified by Jespersen, Griffiths and

498 Wallace (2017) in their comparative analysis of existing food safety culture evaluation systems.

499 It has been questioned whether this dimension should be part of a food safety culture framework

500 or whether it should be considered in the evaluation of food safety management systems and risk

501 awareness (Jespersen and Wallace, 2017) as it is one of the least tangible and least defined

502 dimensions in food safety culture research (De Boeck et al. 2018). However, it was included due 
503 to the importance of understanding the organization's overall approach to managing risks and

504 hazards as opposed to the technical detail of hazard analysis which is addressed in food safety

505 management systems. It is hoped that the delineation of maturity over the Risks and Hazards

506 dimension presented here will help to further understanding of the interactions between cultural

507 and technical systems in food safety.

508 By use of the maturity model and the data collected, an aggregated maturity score was

509 used to calculate aggregated 'cost of poor quality' per company to demonstrate the economic

510 impact the maturity of the company's food safety culture. This cost varied substantially by

511 company, partially due to the dependence on company sales in the equation and the difference in

512 food safety maturity level. As such, cost of poor quality ranged from $\$ 400 \mathrm{M}$ to $\$ 2.4 \mathrm{~B}$ when

513 calculated using Crosby's guidance for percentage per maturity stage (Crosby, 1972). It shows

514 the significance of food safety maturity and its potential economic impact on a food

515 manufacturer's performance.

516 To realize this economic value the research suggests a need to apply learnings from

517 studies that have demonstrated predictive validity of cultural factors and their impact on food

518 safety behaviours and performance. As such, a dynamic model of food safety culture is proposed

519 to better understand the interactions that must be considered when taking steps to mature food

520 safety culture. The four building blocks are: organizational effectiveness, organizational culture

521 norms, learned and shared assumptions of working groups, and individual intent and behaviours.

522 It is proposed that it is through actions and interactions between these building blocks that a food 
523 manufacturer's food safety culture maturity can be evaluated and improved such that the

524 individual employee adapts to organizational norm.

525 This research builds on empirical findings from studies conducted on organizational

526 culture (Denison, 1997; Graham et al., 2017; Guiso et al., 2014; Kotter \& Heskett, 1992) and as

527 such is an adaptation of proven relations between organizational culture and economic

528 performance, as well as the connection between culture, values, norms, and behaviours. The

529 research also makes use of predictive research conducted specifically in the food safety domain

530 and further develops the field of food safety culture by integrating factors impacting food safety

531 performance in the revised maturity model and the food safety culture dynamic model building

532 blocks.

533 It is through the integration of all cultural building blocks and interactions rather than

534 through focus on a single block or action that sustainable results are achieved, that food safety

535 culture is matured, and the company can realize both risk reduction and economic gain. This

536 research is innovative in that it connects maturity, cost of poor quality, and predictive factors of

537 food safety.

538 The limitations in the research lie in its geographical reach, as the participating

539 organizations are global but with headquarters situated in North America. In addition, the five

540 companies were approached to participate in the study based on their previous interests in the

541 subject and willingness to have the researcher collect data virtually and on-site in all their

542 manufacturing plants. As such, the findings may have been affected by existing company 
543 interests in food safety culture and the results cannot be generalised across all food

544 manufacturing plants. Also, the theoretical application of the COPQ proportions has yet to be

545 tested in practice within the food industry. Further research is needed to empirically demonstrate

546 the connection between food safety culture and economic performance and this should be global

547 in scope and include food manufacturing companies of all sizes and representative of all

548 commodities. Similarly, further research is needed to test the food safety dynamic model and

549 interactions across a range of food industry organizations.

550 In conclusion, as food companies recognize more and more the strategic importance of

551 their food safety culture, its reliable and valid evaluation gains importance. This research

552 provides a framework for maturing food safety culture to be integrated into an organization's

553 culture, its values, and norms. By quantifying food safety maturity using a validated,

554 triangulation method, companies can estimate the proportion of their sales wasted through cost of 555 poor quality, and design interventions specific to the four cultural building blocks individually

556 proven to impact food safety performance. This might facilitate a change in the design of 557 interventions to strengthen food safety management and control activities.

\section{6. Acknowledgements}

559 The authors would like to acknowledge, among others, Bush Brothers, Cargill, and Land O'

560 Frost for their leadership and openness to allow this research to take place. 


\section{Tables and Figures}

565 Table 2: COPQ activities and examples of possible quality and food safety activities(Adapted from Duffy, 2017,

566 Hutton, 2001; Surak \& Wilson, 2007; Wallace, Sperber, \& Mortimore, 2011; Mortimore and Wallace, 2013)

\section{COPQ activities Quality examples $\quad$ Food safety examples}

\begin{tabular}{|c|c|c|}
\hline \multirow[t]{4}{*}{ Prevention cost } & Establish specification for & Metal detector calibration, process \\
\hline & incoming ingredients and all & equipment preventative \\
\hline & employee training. & maintenance, and all employee \\
\hline & & training. \\
\hline \multirow[t]{4}{*}{ Appraisal cost } & Quality audits. & Food safety audits. \\
\hline & Checking incoming ingredients & Metal detector checks, \\
\hline & against specification. & environmental monitoring, and \\
\hline & & GMP audits. \\
\hline \multirow[t]{2}{*}{ Internal failure cost } & Waste in the form of products that & Incorrect cooking temperature \\
\hline & cannot be shipped. & causing rework. \\
\hline External failure & Product withdrawal. & Product recall. \\
\hline
\end{tabular}


567 Table 3: Financial performance differences between companies who invested in a performance-enhancing culture 568 and those that did not (Kotter and Heskett, 1992).

\begin{tabular}{lcl}
\hline & $\begin{array}{l}\text { Average increase for 12 } \\
\text { firms with performance- } \\
\text { enhancing cultures }\end{array}$ & $\begin{array}{l}\text { Average increase for 12 } \\
\text { firms without } \\
\text { performance-enhancing } \\
\text { cultures }\end{array}$ \\
\hline Revenue growth & $682 \%$ & $166 \%$ \\
Employment growth & $282 \%$ & $36 \%$ \\
Stock price growth & $901 \%$ & $74 \%$ \\
\hline Net income growth & $756 \%$ & $1 \%$ \\
\hline
\end{tabular}

570 Table 4: Sample statements per area in the self-assessment questionnaire

\begin{tabular}{ll}
\hline Area & Sample statements \\
\hline Social norms & $\begin{array}{l}\text { Most people whose opinion I value would approve if I review the preventive control } \\
\text { plan(s) quarterly to verify effectiveness. } \\
\text { Most people whose opinion I value would approve if I always acknowledge } \\
\text { manufacturing leaders who make good food safety decisions. }\end{array}$ \\
Behavioural intent & $\begin{array}{l}\text { I will do all I can whenever my team does not have the right tools to complete food } \\
\text { safety tasks. } \\
\text { I will improve food safety processes every day } \\
\text { Motivation }\end{array}$ \\
$\begin{array}{l}\text { I want to do what my manager thinks I should do for food safety. } \\
\text { I want to do what I have learned through food safety training. } \\
\text { I appreciate other people's opinions regarding food safety. } \\
\text { It bothers me if people dislike me because of my views about food safety. }\end{array}$ \\
\hline
\end{tabular}

$\begin{array}{lllll}\text { Stages } & & & & \\ \text { Stage 1 } & \text { Stage 2 } & \text { Stage 3 } & \text { Stage 4 } & \text { Stage 5 }\end{array}$




\begin{tabular}{|c|c|c|c|c|c|}
\hline & Doubt & React to & Know of & Predict & Internalize \\
\hline $\begin{array}{l}\text { Stage } \\
\text { characteristic }\end{array}$ & $\begin{array}{l}\text { Most food } \\
\text { safety actions } \\
\text { are taken due to } \\
\text { external } \\
\text { pressures (e.g., } \\
\text { regulators). }\end{array}$ & $\begin{array}{l}\text { Food safety } \\
\text { actions are } \\
\text { solved by the } \\
\text { quality } \\
\text { department } \\
\text { and mostly to } \\
\text { close gaps and } \\
\text { remove issues. }\end{array}$ & $\begin{array}{l}\text { Food safety } \\
\text { knowledge is } \\
\text { prevailing } \\
\text { across the } \\
\text { organization } \\
\text { and everyone } \\
\text { acts to improve } \\
\text { food safety. }\end{array}$ & $\begin{array}{l}\text { Food safety actions } \\
\text { are taken based } \\
\text { mostly on results } \\
\text { from predictive } \\
\text { analysis'. }\end{array}$ & $\begin{array}{l}\text { Food safety } \\
\text { actions are } \\
\text { driven by } \\
\text { everyone and } \\
\text { mostly based on } \\
\text { managing risks. }\end{array}$ \\
\hline $\begin{array}{l}\text { Capability area } \\
\text { characteristic } \\
\text { (sample from } \\
\text { the 'People } \\
\text { System' } \\
\text { capability area) }\end{array}$ & $\begin{array}{l}\text { Individuals } \\
\text { complete food } \\
\text { safety tasks out } \\
\text { of fear for } \\
\text { negative } \\
\text { consequences. }\end{array}$ & $\begin{array}{l}\text { Individuals are } \\
\text { recognized } \\
\text { sporadically } \\
\text { after having } \\
\text { solved a food } \\
\text { safety } \\
\text { problem. }\end{array}$ & $\begin{array}{l}\text { Leaders } \\
\text { recognize } \\
\text { teams and } \\
\text { individuals } \\
\text { according to a } \\
\text { documented } \\
\text { system of } \\
\text { positive and } \\
\text { negative } \\
\text { consequences. }\end{array}$ & $\begin{array}{l}\text { Leaders reward } \\
\text { teams for collectively } \\
\text { improving food } \\
\text { safety } \\
\text { processes/procedures. }\end{array}$ & $\begin{array}{l}\text { Cross } \\
\text { functional/level } \\
\text { teams nominate } \\
\text { other teams for } \\
\text { being proactive } \\
\text { and thinking } \\
\text { strategic around } \\
\text { food safety. }\end{array}$ \\
\hline
\end{tabular}

575 Table 6: Data collected from the five participating companies

\begin{tabular}{|c|c|c|c|c|c|c|}
\hline \multirow[t]{2}{*}{ Data } & \multicolumn{5}{|c|}{ Company } & 576 \\
\hline & A & B & $\mathrm{C}$ & $\mathrm{D}$ & E & $\begin{array}{l}\text { Total } \\
\text { (Mean) }\end{array}$ \\
\hline Number of plants & 11 & 3 & 2 & 2 & 3 & 21 \\
\hline $\begin{array}{l}\text { Survey Response rate } \\
\text { (Percentage) }\end{array}$ & 72 & 77 & 72.5 & 77 & 59 & (72) \\
\hline Performance documents (\#) & 268 & 3 & 33 & 50 & 25 & 379 \\
\hline Interviews (\#) & 22 & 8 & 4 & 4 & 4 & 42 \\
\hline
\end{tabular}

579 able 7: Maturity stages and cost of quality as percentage of sales (Crosby, 1972).

\begin{tabular}{llllll}
\hline Maturity stage & 1 & 2 & 3 & 4 & 5 \\
Percentage (\%) & 20 & 18 & 12 & 8 & 2.5 \\
\hline
\end{tabular}


Table 8: Aggregated company demographics and baseline (mean and total)

\begin{tabular}{|c|c|c|c|c|c|c|c|}
\hline \multirow{2}{*}{ Category } & \multirow{2}{*}{ Measure } & \multicolumn{6}{|c|}{ Company } \\
\hline & & A & B & $\mathrm{C}$ & $\mathrm{D}$ & $\mathrm{E}$ & $\begin{array}{l}\text { Mean } \\
\text { (Total) }\end{array}$ \\
\hline \multirow{7}{*}{ Demographics } & \# plants & 11 & 4 & 2 & 2 & 2 & (21) \\
\hline & $\begin{array}{l}\text { Years in food industry } \\
\text { (mean) }\end{array}$ & $10-14$ & $10-14$ & $10-14$ & $15-19$ & $10-14$ & $10-14$ \\
\hline & $\begin{array}{l}\text { Years in the company } \\
\text { (mean) }\end{array}$ & $10-14$ & $5-9$ & $5-9$ & $10-14$ & $10-14$ & $10-14$ \\
\hline & Years in current role (mean) & $5-9$ & $5-9$ & $2-4$ & $10-14$ & $2-4$ & $5-9$ \\
\hline & Age (mean) & $45-54$ & $34-44$ & $34-44$ & $45-54$ & $34-44$ & $34-44$ \\
\hline & $\begin{array}{l}\text { Functional distribution } \\
\left(\% \mathrm{MFG} / \% \mathrm{FSQ}^{*}\right)\end{array}$ & $86 / 14$ & $82 / 18$ & $92 / 8$ & $85 / 12$ & $78 / 22$ & $\mathrm{n} / \mathrm{a}$ \\
\hline & $\begin{array}{l}\text { Role distribution } \\
\text { (\%Leader/\%Supervisor) }\end{array}$ & $37 / 63$ & $46 / 54$ & $58 / 42$ & $55 / 45$ & $35 / 65$ & $46 / 54$ \\
\hline
\end{tabular}

*Manufacturing and Food Safety \& Quality

583 Table 9: Food safety maturity by company

\begin{tabular}{llllllll}
\hline Category & Measure & Company & & & & & \\
& & A & B & C & D & E & $\begin{array}{l}\text { Mean } \\
\text { (Total) }\end{array}$ \\
\hline Cultural & Culture Stage & Know & Know & React & Know & Predict & Know \\
performance & Maturity [1-5] & 3.36 & 3.31 & 2.80 & 3.05 & 4.01 & 3.3 \\
& Social desirability [1-18] & 4.10 & 7.16 & 7.56 & 6.67 & 4.98 & 6.09 \\
\hline
\end{tabular}

584

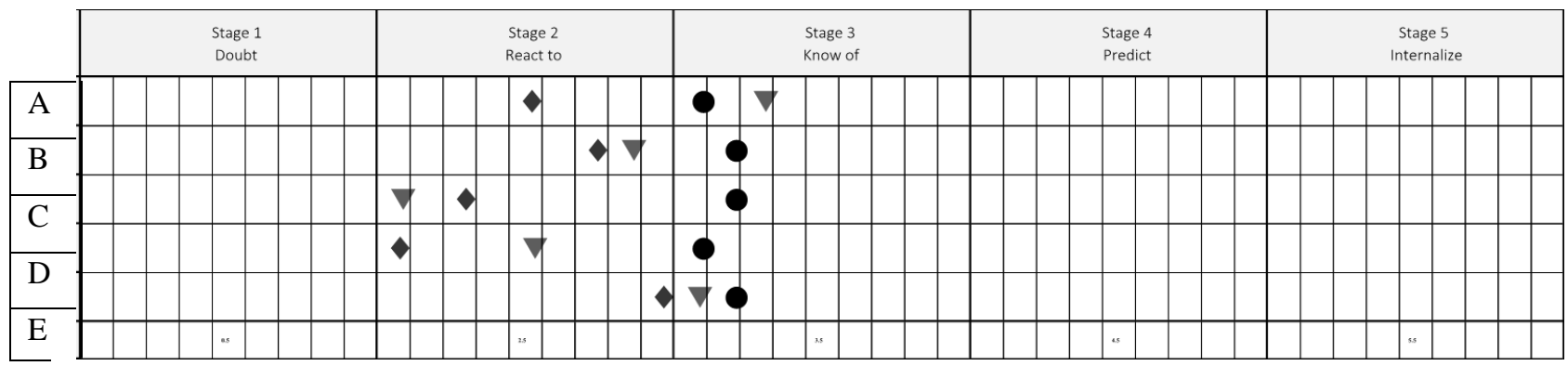

Figure 1: Plant Maturity - Plot of mean values as per method triangulation. Ledger: Dot $=$ Self-assessment scale result, Diamond - Performance document coding result, and Triangle $=$ Interview coding result. 
Table 10: Food safety culture - maturity model version 2.0

Page $\mathbf{3 5}$ of $\mathbf{4 5}$ 


\begin{tabular}{|c|c|c|c|c|c|c|}
\hline \multirow[b]{2}{*}{ Dimension } & \multirow[b]{2}{*}{ Values } & \multicolumn{5}{|l|}{ Stage } \\
\hline & & $\begin{array}{l}\text { Stage } 1 \\
\text { Doubt }\end{array}$ & $\begin{array}{l}\text { Stage } 2 \\
\text { React }\end{array}$ & $\begin{array}{l}\text { Stage } 3 \\
\text { Know }\end{array}$ & $\begin{array}{l}\text { Stage } 4 \\
\text { Predict }\end{array}$ & $\begin{array}{l}\text { Stage 5 } \\
\text { Internalize }\end{array}$ \\
\hline \multirow[t]{3}{*}{$\begin{array}{l}\text { Values and } \\
\text { Mission }\end{array}$} & $\begin{array}{l}\text { Integrity and } \\
\text { trust }\end{array}$ & $\begin{array}{l}\text { Employees have little } \\
\text { trust that management } \\
\text { will act on food } \\
\text { safety without } \\
\text { external pressure }\end{array}$ & $\begin{array}{l}\text { Employees trust that } \\
\text { management will act } \\
\text { and do the right thing } \\
\text { for food safety after } \\
\text { an issue have } \\
\text { occurred }\end{array}$ & $\begin{array}{l}\text { Everyone trusts that } \\
\text { food safety issues are } \\
\text { solved because we } \\
\text { know it protects our } \\
\text { business }\end{array}$ & $\begin{array}{l}\text { Everybody is trusted } \\
\text { to invest in food } \\
\text { safety information to } \\
\text { make future } \\
\text { performance stronger }\end{array}$ & $\begin{array}{l}\text { Frontline employees } \\
\text { are trusted to act } \\
\text { correct and celebrate } \\
\text { food safety } \\
\text { performance on their } \\
\text { line/in their area }\end{array}$ \\
\hline & $\begin{array}{l}\text { Being } \\
\text { responsible }\end{array}$ & $\begin{array}{l}\text { Nobody knows who } \\
\text { has the duty to deal } \\
\text { with food safety }\end{array}$ & $\begin{array}{l}\text { Everybody readily } \\
\text { takes responsibility, } \\
\text { but it is unclear what } \\
\text { that means }\end{array}$ & $\begin{array}{l}\text { Detailed food safety } \\
\text { responsibility is } \\
\text { written into job } \\
\text { descriptions for } \\
\text { everybody }\end{array}$ & $\begin{array}{l}\text { Decision makers are } \\
\text { certified food safety } \\
\text { professionals and } \\
\text { responsible for } \\
\text { driving cost out of the } \\
\text { food safety system }\end{array}$ & $\begin{array}{l}\text { Frontline is responsible } \\
\text { for bubbling } \\
\text { improvement plans to } \\
\text { leaders, leaders are } \\
\text { responsible for } \\
\text { incorporating these } \\
\text { into long-term business } \\
\text { planning }\end{array}$ \\
\hline & Ethics & $\begin{array}{l}\text { Moral principle } \\
\text {..don't look }\end{array}$ & $\begin{array}{l}\text { Moral } \\
\text { principle...invest if } \\
\text { we must }\end{array}$ & $\begin{array}{l}\text { Moral } \\
\text { principle...improve } \\
\text { system }\end{array}$ & $\begin{array}{l}\text { Moral } \\
\text { principle...reduce cost } \\
\text { by taking out } \\
\text { variation }\end{array}$ & $\begin{array}{l}\text { Moral principle...grow } \\
\text { business }\end{array}$ \\
\hline \multirow[t]{3}{*}{ People System } & $\begin{array}{l}\text { Reward and } \\
\text { recognize }\end{array}$ & $\begin{array}{l}\text { Individuals complete } \\
\text { food safety tasks out } \\
\text { of fear for negative } \\
\text { consequences }\end{array}$ & $\begin{array}{l}\text { Individuals are } \\
\text { recognized } \\
\text { sporadically after } \\
\text { having solved a food } \\
\text { safety problem }\end{array}$ & $\begin{array}{l}\text { Leaders recognize } \\
\text { teams and individuals } \\
\text { according to a } \\
\text { documented system } \\
\text { of positive and } \\
\text { negative } \\
\text { consequences }\end{array}$ & $\begin{array}{l}\text { Leaders reward teams } \\
\text { for collectively } \\
\text { improving food safety } \\
\text { processes/procedures }\end{array}$ & $\begin{array}{l}\text { Cross functional/level } \\
\text { teams nominate other } \\
\text { teams for being } \\
\text { proactive and thinking } \\
\text { strategic around food } \\
\text { safety }\end{array}$ \\
\hline & $\begin{array}{l}\text { Competently } \\
\text { communicating }\end{array}$ & $\begin{array}{l}\text { Top-down 'tell' with } \\
\text { little 'why' content } \\
\text { and understanding of } \\
\text { the importance of the } \\
\text { task }\end{array}$ & $\begin{array}{l}\text { Food safety } \\
\text { information is } \\
\text { communicated by } \\
\text { FSQ as problems } \\
\text { occur using, if } \\
\text { available, facts } \\
\text { discovered as the } \\
\text { problem was solved }\end{array}$ & $\begin{array}{l}\text { There is a deep } \\
\text { understanding of the } \\
\text { food safety system } \\
\text { and performance is } \\
\text { communicated by } \\
\text { some functional } \\
\text { leaders on a regular } \\
\text { basis }\end{array}$ & $\begin{array}{l}\text { Frontline leaders are } \\
\text { having regular } \\
\text { communications on } \\
\text { food safety } \\
\text { performance using } \\
\text { data and tracking the } \\
\text { teams' improvement } \\
\text { actions }\end{array}$ & $\begin{array}{l}\text { Food safety } \\
\text { communication } \\
\text { cadence is an } \\
\text { organizational habit } \\
\text { that indBages } \mathbf{3 6} \text { of } \mathbf{4 5} \\
\text { everybody in specific } \\
\text { team discussions }\end{array}$ \\
\hline & $\begin{array}{l}\text { Together we } \\
\text { make the } \\
\text { difference }\end{array}$ & silos... & $\begin{array}{l}\text { problem } \\
\text { communication... }\end{array}$ & $\begin{array}{l}\text { fragmented delivery } \\
\text { of information... }\end{array}$ & $\begin{array}{l}\text { Food safety and } \\
\text { quality critical } \\
\text { conversations... }\end{array}$ & habit... \\
\hline
\end{tabular}


Page $\mathbf{3 7}$ of $\mathbf{4 5}$ 


\begin{tabular}{|c|c|c|c|c|c|c|}
\hline \multirow[t]{2}{*}{ Adaptability } & Innovate & $\begin{array}{l}\text { Scrambling to meet } \\
\text { changed requirements }\end{array}$ & $\begin{array}{l}\text { Aware of coming } \\
\text { change but do not } \\
\text { update procedures } \\
\text { before last minute }\end{array}$ & $\begin{array}{l}\text { Change is analysed } \\
\text { and incorporated into } \\
\text { written food safety } \\
\text { system including } \\
\text { changes to } \\
\text { competencies/job } \\
\text { descriptions }\end{array}$ & $\begin{array}{l}\text { Innovation is driven } \\
\text { by data internally to } \\
\text { reduce food safety } \\
\text { costs }\end{array}$ & $\begin{array}{l}\text { Innovation is suggested } \\
\text { by frontline teams and } \\
\text { bubbling up to impact } \\
\text { companywide system. } \\
\text { Quick to adapt as they } \\
\text { have technology } \\
\text { interface in their hands }\end{array}$ \\
\hline & $\begin{array}{l}\text { Embrace and } \\
\text { drive change }\end{array}$ & $\begin{array}{l}\text { Nothing is stable, so } \\
\text { it does not matter if } \\
\text { we must } \\
\text { change... again }\end{array}$ & $\begin{array}{l}\text { We know change is } \\
\text { coming and will deal } \\
\text { with it last minute... }\end{array}$ & $\begin{array}{l}\text { We know the change } \\
\text { and have analysed the } \\
\text { impact on individuals } \\
\text { and teams according } \\
\text { to a pre-defined } \\
\text { change curve... }\end{array}$ & $\begin{array}{l}\text { We look for cost } \\
\text { reduction } \\
\text { opportunities and } \\
\text { plan these in our } \\
\text { continuous } \\
\text { improvement } \\
\text { program... }\end{array}$ & $\begin{array}{l}\text { Frontline teams have } \\
\text { full autonomy to drive } \\
\text { change in the food } \\
\text { safety system, support } \\
\text { teams are responsible } \\
\text { for spreading new and } \\
\text { best practices across } \\
\text { the company... }\end{array}$ \\
\hline \multirow[t]{3}{*}{ Consistency } & $\begin{array}{l}\text { Data and } \\
\text { reporting }\end{array}$ & $\begin{array}{l}\text { Data are not used to } \\
\text { solve problems and } \\
\text { mostly sitting in a } \\
\text { filing cabinet or in } \\
\text { unused reports }\end{array}$ & $\begin{array}{l}\text { It is left to the } \\
\text { individual to identify } \\
\text { needed data and ways } \\
\text { to derive information } \\
\text { from these }\end{array}$ & $\begin{array}{l}\text { Leading indicators } \\
\text { are used to find root } \\
\text { causes of food safety } \\
\text { problems and } \\
\text { solutions are built } \\
\text { into the food safety } \\
\text { management system }\end{array}$ & $\begin{array}{l}\text { Leading indicators } \\
\text { are continuously } \\
\text { updated through } \\
\text { precisely and } \\
\text { accurately collected } \\
\text { data }\end{array}$ & $\begin{array}{l}\text { Frontline teams and } \\
\text { supervisors make use } \\
\text { of leading indicators to } \\
\text { improve food safety } \\
\text { systems }\end{array}$ \\
\hline & $\begin{array}{l}\text { Technology } \\
\text { enabled success }\end{array}$ & $\begin{array}{l}\text { Little to no new value } \\
\text { placed on buying or } \\
\text { adopting technology }\end{array}$ & $\begin{array}{l}\text { Technology is bought } \\
\text { in reaction to a } \\
\text { specific need e.g., } \\
\text { faster pathogen } \\
\text { testing results }\end{array}$ & $\begin{array}{l}\text { Technology is seen in } \\
\text { the context of the } \\
\text { business system to } \\
\text { integrate functions, } \\
\text { procedures, and } \\
\text { capabilities (e.g., } \\
\text { ERP specification } \\
\text { system) }\end{array}$ & $\begin{array}{l}\text { Automation is used } \\
\text { frequently and seen } \\
\text { as an integral part of } \\
\text { reducing food safety } \\
\text { cost }\end{array}$ & $\begin{array}{l}\text { Enterprise Resource } \\
\text { Planning (ERP) is used } \\
\text { in an integrated way } \\
\text { with automated } \\
\text { workflows that make } \\
\text { the enterprise quick to } \\
\text { adapt }\end{array}$ \\
\hline & $\begin{array}{l}\text { Quality of all } \\
\text { we do }\end{array}$ & $\begin{array}{l}\text { Unstructured problem } \\
\text { solving to remove the } \\
\text { immediate pain }\end{array}$ & $\begin{array}{l}\text { 'plan, do, check, act' } \\
\text { with emphasis on } \\
\text { control and } \\
\text { expectation of } 100 \% \\
\text { perfect solutions from } \\
\text { the start }\end{array}$ & $\begin{array}{l}\text { Structured, } \\
\text { documented problem } \\
\text { solving with high risk } \\
\text { of analysis paralysis }\end{array}$ & $\begin{array}{l}\text { 'plan, do, study, act' } \\
\text { with emphasis on } \\
\text { study and an iterative } \\
\text { approach to } \\
\text { improvement }\end{array}$ & $\begin{array}{l}\text { Identifying risks } \\
\text { through horizon } \\
\text { scanning and } \\
\text { continupus } \\
\text { improvement followed } \\
\text { by mitigation plans } \\
\text { built into the food } \\
\text { safety system }\end{array}$ \\
\hline $\begin{array}{l}\text { Risks and } \\
\text { Hazards }\end{array}$ & Risk perception & $\begin{array}{l}\text { The organization } \\
\text { relies mostly on } \\
\text { external sources and } \\
\text { inspections to } \\
\text { understand and act on } \\
\text { its risks and doesn't } \\
\text { identify risks } \\
\text { internally }\end{array}$ & $\begin{array}{l}\text { Actions to manage } \\
\text { risks are mostly taken } \\
\text { in response to } \\
\text { external audits or } \\
\text { inspections and } \\
\text { internal identification } \\
\text { is sometimes } \\
\text { incorrect }\end{array}$ & $\begin{array}{l}\text { Risks are understood } \\
\text { and continually } \\
\text { challenged by a } \\
\text { cross-functional team } \\
\text { through planned risk } \\
\text { management }\end{array}$ & $\begin{array}{l}\text { Understanding and } \\
\text { reducing risks are an } \\
\text { integral part of the } \\
\text { organization's } \\
\text { continuous } \\
\text { improvement efforts }\end{array}$ & $\begin{array}{l}\text { The organization relies } \\
\text { on frontline teams to } \\
\text { manage existing risks } \\
\text { and to identify new } \\
\text { ones through peer } \\
\text { observations }\end{array}$ \\
\hline
\end{tabular}




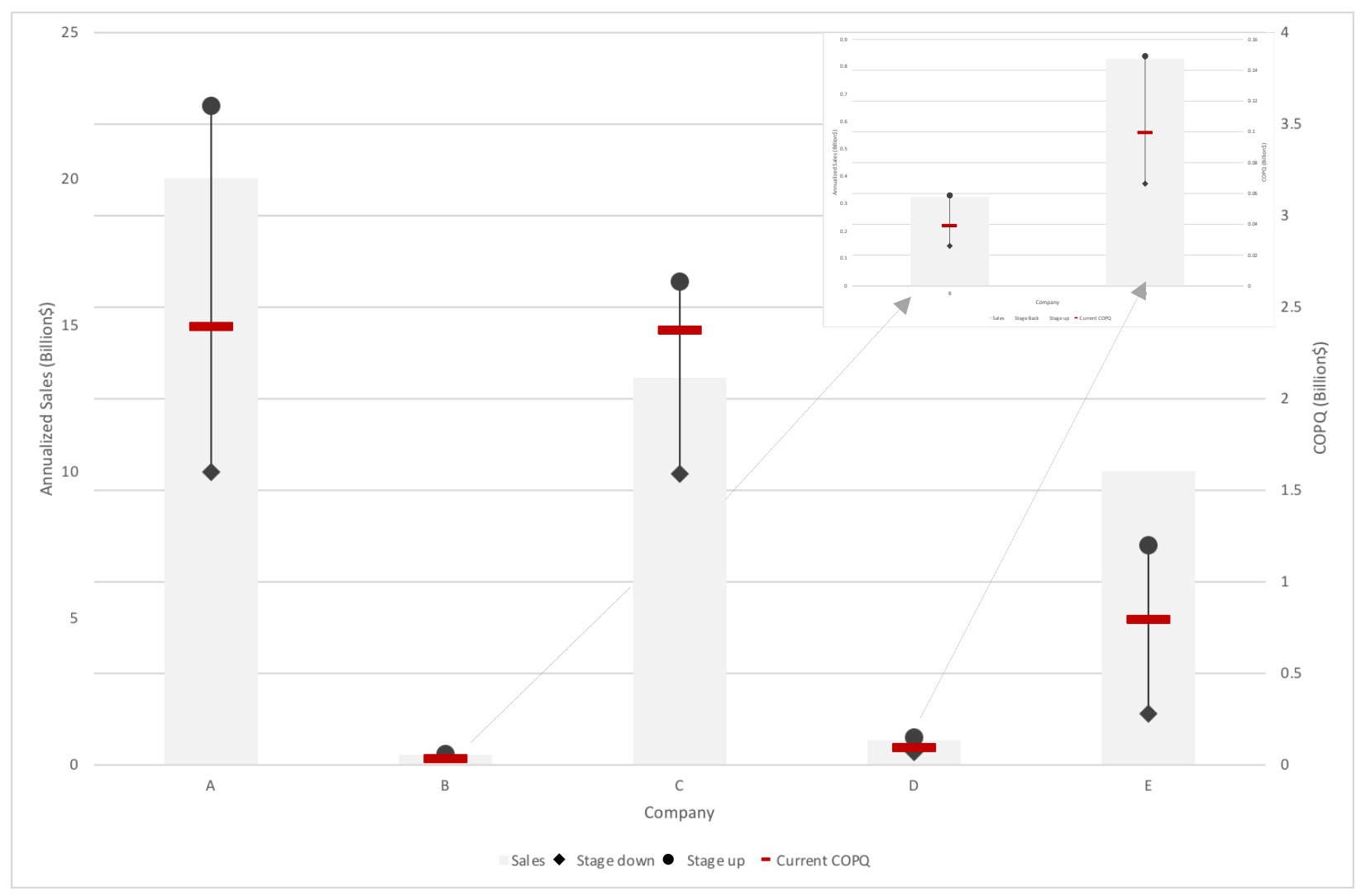

591 Figure 2: Annualized sales per company and COPQ based on evaluation result (bar), one maturity stage up (dot), 592 and one stage down (diamond).

593

594 
I. Organizational effectiveness

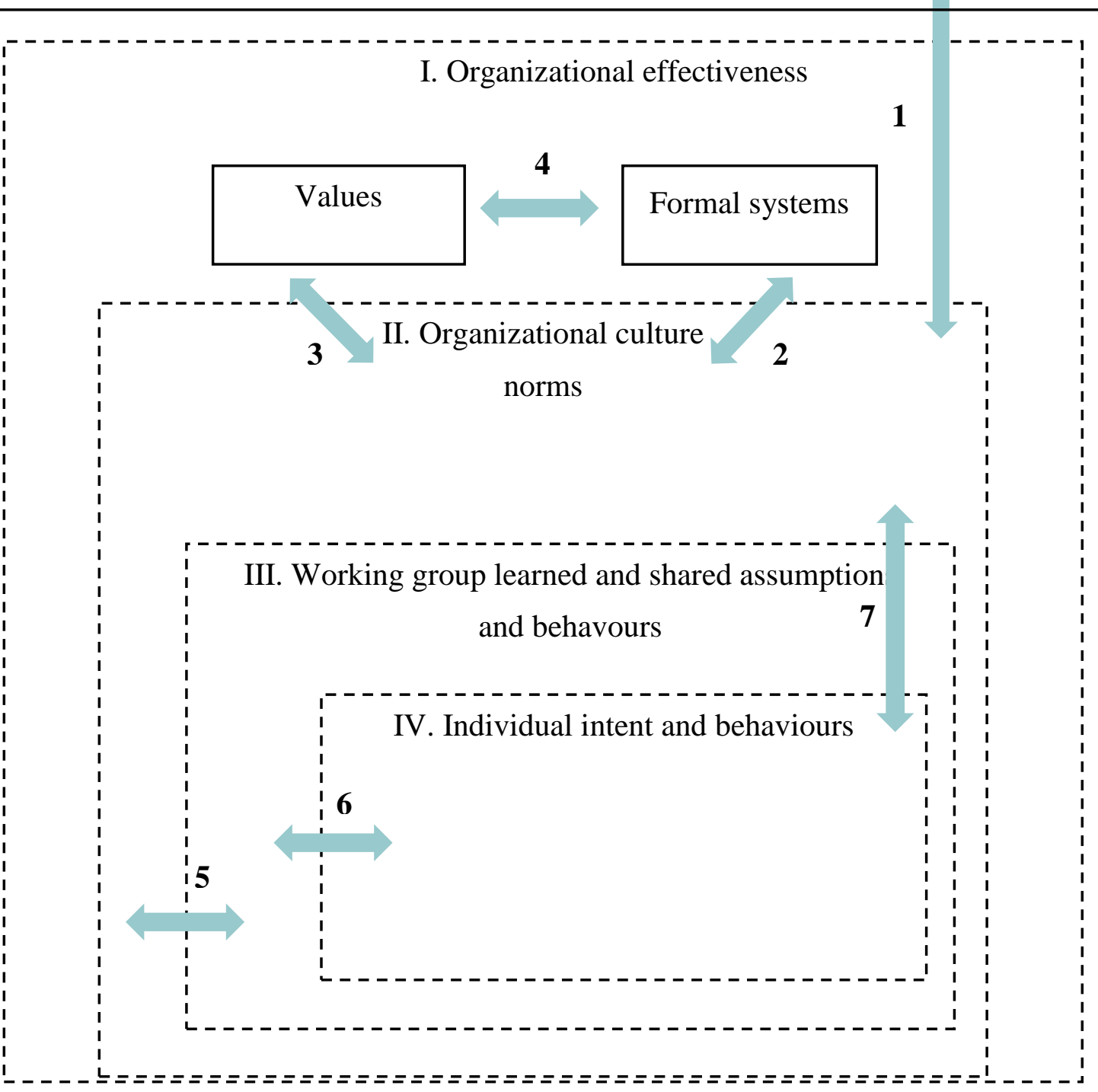

Figure 3: Dynamic model of a culture of food safety

'Interactions' e.g., adapt and integrate

Culture building blocks

External environment boundary 
600 Annex 1: Coding process applied to deriving data through content analysis (Source: Jespersen 601 and Wallace, 2017)

602

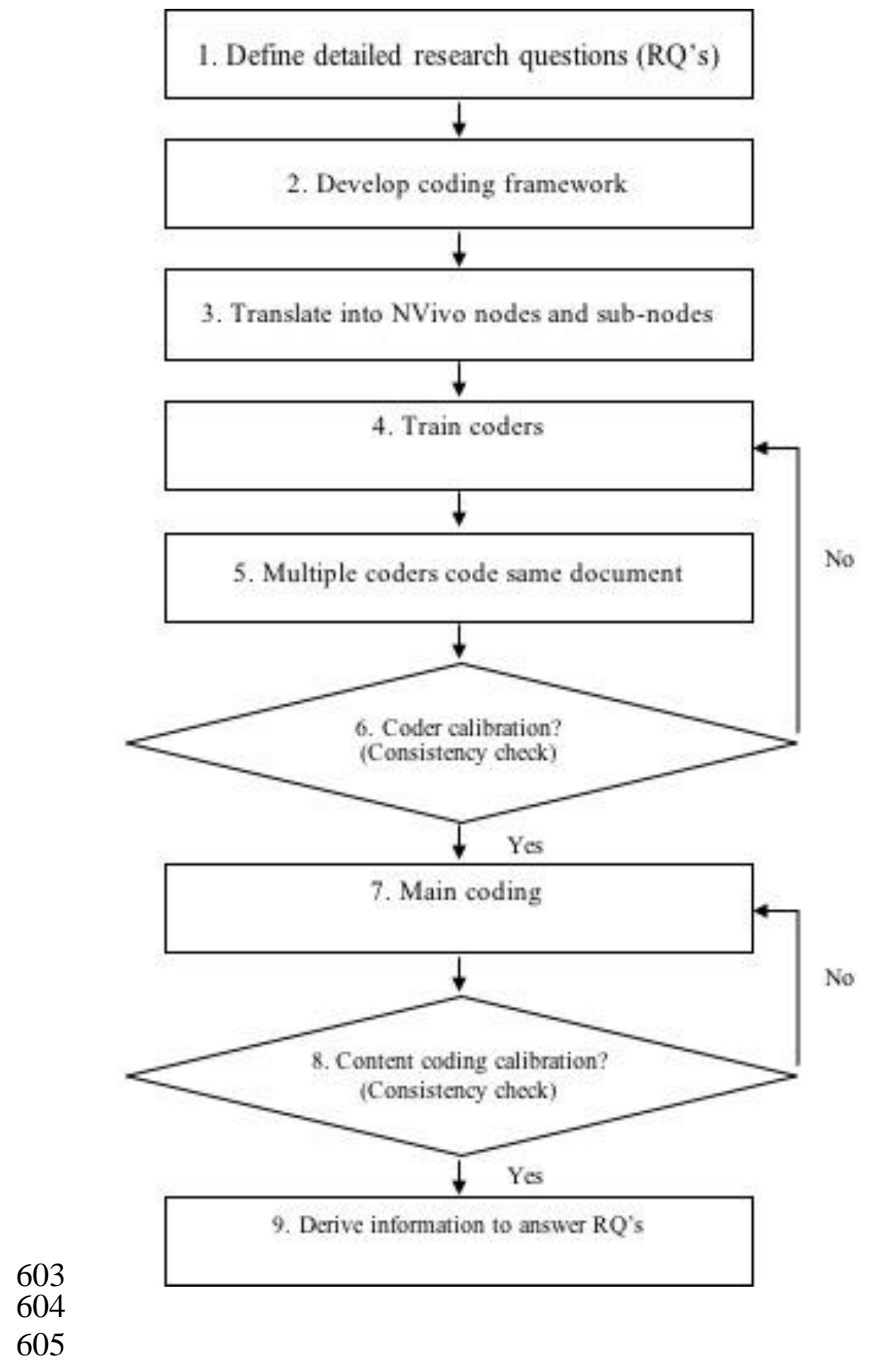


607 Annex 11: Coding framework used in the content analysis of textual data (Semi-structured

608 interviews and performance documents) (Source: Jespersen and Wallace (2017)).

\begin{tabular}{|c|c|}
\hline Node & Sub-Nodes \\
\hline Values and Mission & $\begin{array}{l}\text { Compliance. } \\
\text { Measures/metrics/KPIs. } \\
\text { Mission, vision, goals. } \\
\text { Ownership/owning. } \\
\text { Plan/roadmap, direction. } \\
\text { Recall/recalls/withdrawals. } \\
\text { Responsibility, accountability, commitment. } \\
\text { Direction, setting expectations, corporate direction. } \\
\text { Financials, budgets, and prioritizing. }\end{array}$ \\
\hline People Systems & $\begin{array}{l}\text { Any reference to persons' role/education/job and group or team and references to individuals. } \\
\text { Behaviour/practice, work routine. } \\
\text { Communication and dialog. } \\
\text { Involvement. } \\
\text { Consequence, escalation. } \\
\text { Pride. } \\
\text { Rewards and celebration. } \\
\text { Training, education, learning, proficiency. } \\
\text { Cross-functional. } \\
\text { Unionized. } \\
\text { Rotation and retention. } \\
\text { "Making choices..." }\end{array}$ \\
\hline Consistency & $\begin{array}{l}\text { Actions, tasks, action due date. } \\
\text { Non-conformance, reoccurring. } \\
\text { Technology. } \\
\text { Tools, infrastructure, and policies/procedures. } \\
\text { References to third party standards. } \\
\text { Problems, breakdowns, and issues. }\end{array}$ \\
\hline Adaptability & $\begin{array}{l}\text { Change readiness, open to change, change ready. } \\
\text { Improvement, must improve, continuous improvement, improvement process, improvement } \\
\text { system, continuous improvement, Six Sigma, Lean manufacturing. }\end{array}$ \\
\hline Risks and Hazards & $\begin{array}{l}\text { Leaders risk awareness and perception. } \\
\text { Operator risk awareness and perception. } \\
\text { Risks, hazards. }\end{array}$ \\
\hline
\end{tabular}

609 


\section{References}

613

614

615

616

617

618

619

620

621

622

623

624

625

626

627

628

629

630

631

632

633

634

635

636

637

638

639

640

641

642

643

644

645

646

647

648

649

650

651

652

653

654

655

656

Ali, S. (2014). Strategic Planning Using COBIT 5. Retrieved from https://www.isaca.org/KnowledgeCenter/cobit/Documents/CF-Vol-2-2014-Strategic-Planning-Using-COBIT-5_nlt_Eng_0414.pdf

Ball, B., Wilcock, A., \& Aung, M. (2009). Factors influencing workers to follow food safety management systems in meat plants in Ontario, Canada. International journal of environmental health research, 19(3), 201-218. doi:10.1080/09603120802527646

Boeck, D., Jacxsens, Bollaerts, \& Vlerick. (2015). Food safety climate in food processing orgaizations: Development and validation of a self-assessment tool. Trends in Food Science \& Technology, 46(2015), 242-251.

Boyce, A. S., Nieminen, L. R. G., Gillespie, M. A., Ryan, A. M., \& Denison, D. R. (2015). Which comes first, organizational culture or performance? A longitudinal study of causal priority with automobile dealerships. Journal of Organizational Behavior, 36(3), 339-359.

Crosby, P. B. (1972). Quality is Free: McGraw-Hill.

De Boeck, E., Mortier, A. V., Jacxsens, L., Dequidt, L., \& Vlerick, P. (2017). Towards an extended food safety culture model: Studying the moderating role of burnout and jobstress, the mediating role of food safety knowledge and motivation in the relation between food safety climate and food safety behavior. Trends in Food Science \& Technology, 1-13.

Denison, D. R. (1997). Corporate Culture and Organizational Effectiveness (Vol. 2nd edition (May 1997)): Aviat.

Denison, D. R., Hooijberg, R., Lane, N., \& Lief, C. (2012). Leading Culture Change in Global Organizations: Aligning Culture and Strategy. John Wiley \& Sons.

Denison, D. R., \& Mishra, A. K. (1995). Toward a Theory of Organizational Culture and Effectiveness. Organization Science, 6(2), 204-223.

Denzin, N. K. (2012). Triangulation 2.0. Journal of Mixed Methods Research, 6(2), 80-88. doi:10.1177/1558689812437186

Duffy, G. L. (2017). COST OF QUALITY (COQ). Retrieved from http://asq.org/learn-aboutquality/cost-of-quality/overview/overview.html

Goonan, K. J., Muzikowski, J. A., \& Stoltz, P. K. (2009). Journey to excellence: how Baldridge Health Care leaders succeed. Milwaukee, WI: American Society for Quality, Quality Press.

Graham, J. R., Harvey, C. R., Popadak, J., \& Rajgopal, S. (2017). Corporate Culture: Evidence from the Field. Retrieved from The National Bureau of Economic Research:

Great-Place-to-Work. (2017). Three Predictions for the Workplace Culture of the Future. Retrieved from https://www.greatplacetowork.com/images/reports/Fortune_100_Report_2017_FINAL.pdf

Griffith, C. J. (2010). Do businesses get the food poisoning they deserve? British Food Journal, 112(4), 416-425. doi:10.1108/00070701011034420

Griffith, C. J. (2014). Developing and Maintaining a Positive Food Safety Culture. Highfield.co.uk Limited.

Griffith, C. J., \& Jackson, L. M. L., Ryk (2017). The food safety culture in a large South African food service complex: Perspectives on a case study. British Food Journal, 119(4), 729-743. doi:doi:10.1108/BFJ-11-2016-0533

Guiso, L., Sapienza, P., \& Zingales, L. (2014). The value of corporate culture. Journal of Financial Economics, 117(1), 60-76.

Hinsz, V. B., \& Nickell, G. S. (2015). The prediction of workers' food safety interntions and behavior with job attitudes and the reasoned action approach. Journal of Work and Organizational Psychology, 31, 91-100. 
Hussain, M. A., \& Dawson, C. O. (2013). Economic Impact of Food Safety Outbreaks on Food Businesses. Foods(2), 585-589.

Hutton, T. (2001). Food manufacturing: an overview: Campden \& Chorleywood Food research Accociation Group.

Jespersen, L. (2017). Supply chain and food safety culture. Food Safety Magazine, February - March.

Jespersen, L., \& Edwards, A. M. (Submitted). Predictive Attributes of Food Safety Culture and Climate.

Jespersen, L., Griffiths, M., Maclaurin, T., Chapman, B., \& Wallace, C. A. (2016). Measurement of food safety culture using survey and maturity profiling tools. Food Control, 66, 174-182. doi:http://dx.doi.org/10.1016/j.foodcont.2016.01.030

Jespersen, L., Griffiths, M., \& Wallace, C. A. (2017). Comparative analysis of existing food safety culture evaluation systems. Food Control, 79, 371-379. doi:https://doi.org/10.1016/j.foodcont.2017.03.037

Jespersen, L., MacLaurin, T., \& Vlerick, P. (2017). Development and validation of a scale to capture social desirability in food safety culture. Food Control.

Jespersen, L., \& Wallace, C. A. (2017). Triangulation and the importance of establishing valid methods for food safety culture evaluation Food Research International.

Kotter, J. P., \& Heskett, J. L. (1992). Corporate culture and performance: The Free Press.

Lombard, M., Snyder-Duch, J., \& Bracken, C. C. (2002). Content Analysis in Mass Communication: Assessment and Reporting of Intercoder Reliability. Human Communication Research, 28(4), 587-604. doi:10.1111/j.1468-2958.2002.tb00826.x

Maberry, T. (2016). A Look Back at 2015 Food Recalls. Retrieved from http://www.foodsafetymagazine.com/enewsletter/a-look-back-at-2015-food-recalls/

Manning, L. (2017). The Influence of Organizational Subcultures on Food Safety Management. Journal of Marketing Channels, 24(3-4), 180-189. doi:10.1080/1046669X.2017.1393235

Nayak, R., \& Waterson, P. (2017). The Assessment of Food Safety Culture: An investigation of current challenges, barriers and future opportunities within the food industry. Food Control, 73(Part B), 1114-1123. doi:https://doi.org/10.1016/j.foodcont.2016.10.061

Neuendorf, K. A. (2002). The content analysis guidebook: Thousand Oaks : Sage Publications.

Nickell, G. S., \& Hinsz, V. B. (2011). Having a conscientious personality helps an organizational climate of food safety predict food safety behavior. In B. W. Marion (Ed.), Food Supplies and Food Safety (pp. 189-198).

Nyarugwe, S. P., Linnemann, A., Hofstede, G. J., Fogliano, V., \& Luning, P. A. (2016). Determinants for conducting food safety culture research. Trends in Food Science \& Technology, 56(Supplement C), 77-87. doi:https://doi.org/10.1016/j.tifs.2016.07.015

Powell, D. A., Jacob, C. J., \& Chapman, B. J. (2011). Enhancing food safety culture to reduce rates of foodborne illness. Food Control, 22(6), 817-822. doi:10.1016/j.foodcont.2010.12.009

Quentin, M. C., \& Jespersen, L. (2018). A Culture of Food Safety. Retrieved from http://www.mygfsi.com/news-resources/news/news-blog/1419-a-culture-of-food-safety.html

Ribera, L. A., Palma, M. A., Paggi, M., Knutson, R., Masabni, J. G., \& Anciso, J. (2012). Economic Analysis of Food Safety Compliance Costs and Foodborne Illness Outbreaks in the United States. HortTechnology(22(2)), 150-156.

Schein, E. H. (2004). Organizational culture and leadership. San Francisco: San Francisco : Jossey-Bass. Schein, E. H., \& Schein, P. (2017). Organizational Culture and Leadership: Wiley.

Schiffauerova, A., \& Thomson, V. (2006). A review of research on cost of quality models and best practices. International Journal of Quality \& Reliability Management, 23(6), 647-669.

Surak, J. G., \& Wilson, S. (2007). The Certified HACCP Auditor: American Society for Quality. 
Taylor, J. (2011). An exploration of food safety culture in a multi-cultural environment: next steps? Worldwide Hospitality and Tourism Themes, 3(5), 455-466. doi:http://dx.doi.org.subzero.lib.uoguelph.ca/10.1108/17554211111185836

Taylor, J., Garat, J. P., Simreen, S., \& Sarieddine, G. (2015). An industry perspective: A new model of Food Safety Culture Excellence and the impact of audit on food safety standards. Worldwide Hospitality and Tourism Themes, 7(1), 78-89. Retrieved from http://sfx.scholarsportal.info/guelph/docview/1648846697? accountid=11233.

Wallace, C. A. (2009). The impact of personnel, training, culture and organisational factors on the application of the HACCP system for food safety management in a multinational organisation, . (PhD Thesis).

Wallace, C. A., Holyoak, L., Powell, S. C., \& Dykes, F. C. (2012). Re-thinking the HACCP team: An investigation into HACCP team knowledge and decision-making for successful HACCP development. Food Research International, 47(2), 236-245. doi:10.1016/j.foodres.2011.06.033

Wallace, C. A., Sperber, W., \& Mortimore, S. E. (2010). Food Safety for the 21 st Century: Managing HACCP and Food Safety throughout the Global Supply Chain: Wiley-Blackwell.

World-Health-Organization. (2015). Global burden of foodborne diseases. Retrieved from http://www.who.int/foodsafety/areas_work/foodborne-diseases/ferg/en/

Yiannas, F. (2009). Food safety culture creating a behavior-based food safety management system: New York : Springer, c2009. 